\title{
"ANYTHING HONEST TO SELL BOOKS": WALT WHITMAN AND THE AUTOGRAPH MONSTER
}

\author{
ERIC CONRAD
}

WALT WHITMAN CLAIMED to have "no rigid rule" for dealing with autograph requests, but towards the end of his life he had become well known among contemporaries for his cautious approach to swarming signature seekers. ${ }^{1}$ During the mid-nineteenth century, the persistence of what Whitman called the "autograph monster"-a growing number of men and women who begged and often lied their way to signatures from the nation's leading poets and novelists-signaled America's rapidly increasing appetite for collecting and consuming celebrity personalities ( $W W W C, 3: 496$ ). For Whitman, this monster was simply a fact of life. "Not a day but the autograph hunter is on my trail — chases me, dogs me! . . . Their subterfuges, deceptions, hypocrisies, are curious, nasty, yes damnable," Whitman complained to Horace Traubel. No request was to be met naively; even a letter from a young girl could bear "the grin of an old deceiver," an "old subterfuge" the poet often met with a laugh ( $W W W C, 2: 82-83 ; 3: 410-411){ }^{2}$ Monsters were everywhere.

Whitman's life would become punctuated by encounters with these persistent collectors. "I have no mail today except an autograph mail," Whitman tells Traubel in 1888: "an autograph mail, yes, and that I get every day. They all write me-hundreds write-strangers-they all beg autographs - tell funny tales about it, give funny reasons (some of them are pitiful — some of them are almost piteous) - I practically never answer them anymore. It takes about all the strength I have nowadays to keep the flies off" ( $W W W C, 1: 366$ ). Though Whitman's autograph would never become as revered by contemporary collectors as those of the signers of the Declaration of Independence-signatures that inspired their own cult following - the poet's canny management of his signature would earn him a unique place among literary professionals. Whitman's relationship with the autograph monster was markedly ambivalent, and, as I will argue, that ambivalence had a tremendous impact on the design and marketing of his final books. Like so many brands before and after him, Whitman would place a signature-his signature, written by hand or reproduced mechanically - at the center 
of his commercial identity. Spanning from the 1868 British edition of Poems by Walt Whitman, the first Whitman-book to include a facsimile of the poet's autograph, to the 1892 "deathbed" edition of Leaves of Grass, Whitman's signature-produced in and on his books and requested every day through the mail-became an increasingly prominent marker of his personality and literary work.

This essay traces Whitman's relationship to the culture of autograph collecting during the nineteenth century. I begin by examining the emergence of the autograph hunter in America, focusing especially on the cultural significance of the celebrity signature after the Civil War and the relationships collectors developed with well-known writers like Longfellow, Whittier, Lowell, Howells, and Holmes. Whitman was far more protective of his autograph than his poetic peers; that guarded stance came to influence the way Whitman circulated his signature within the covers of Leaves of Grass, where he included it several times as part of a preconceived promotional scheme. Whitman's signature would become a central emblem of his literary brand-it appears in and/or on nearly every volume the poet published from 1881 until his death in 1892 - the perfect symbol of what David Haven Blake identifies as "Whitman's remarkable merger of poetry and publicity."” Whitman's efforts to join his autograph with his poetry tapped into the emergence of what Tamara Plakins Thornton calls the "handwriting romantics"- autograph collectors and handwriting analysts-subcultures with a taste for tokens of celebrity that some believed could reveal the character of their inscriber. ${ }^{4}$ For Whitman, the autograph was not only a new and foolproof way to drum up business; it was yet another strategy to emphasize the author's place within Leaves of Grass through the signature's "transcendental form of presentness." 5

Competing accounts make it unclear whether Whitman actually believed his signature was unique. William Douglas O'Connor, Whitman's trusted abolitionist friend and author of The Good Gray Poet, once took the poet's autograph to a clerk in Washington, D.C., to have it copied. The Treasury Department employee "so cleverly duplicated" the signature that Whitman later admitted, "I could not myself tell the two apart" ( $W W W C, 1: 201)$. But, on a separate occasion, Whitman describes an incident involving a similar "expert" in Washington who insisted the poet's autograph was "one of the hardest he knew to imitate." The unnamed man, whom Whitman describes as having "a distinct genius," including an uncanny ability to "imitate pretty near any signature at will," could very well be the same Treasury employee that O'Connor knew, yet here Whitman reaches a completely different conclusion about the inimitability of his autograph. Whitman boasts of the master copyist's inability to convincingly recreate his hand. 
"It must be as the expert said," Whitman tells Traubel in 1891, "[my signature's] very simplicity protects it . . . just as simplicity, truth, can never be imitated" (WWWC, 8:276). ${ }^{6}$

Even if Whitman himself was uncertain about the singularity of his autograph, for American literary consumers during the nineteenth century Whitman's signature was indeed distinctive: it signified a unique and recognizable literary brand. Walter Whitman could not legally protect the signature of "Walt Whitman" as a trademark, yet his autograph nonetheless acted as the "mark of a distinct textual product."7 In his insightful analysis of Mark Twain's failed attempt to trademark his pen name, Loren Glass offers an appraisal of late-nineteenth- and twentiethcentury literary celebrity that undergirds this project. "Twain's attempts to trademark his pen name," Glass writes, announce "a new model of U.S. authorship - one that legitimates literary property less as a mark of intellectual labor than as an index of cultural recognition" (59). Approaching the "authorial signature and name as a trademark provides [us] a conceptual register for understanding the cultural meanings of celebrity authorship more generally in the United States" (82). Provoked by the incessant demand for his autograph, Whitman transformed his signature into a "metaphoric form of trademark," a symbol of his "cultural recognition," and a central image of his commercial presence (81).

The daily rhythms of Whitman's last years in Camden, New Jersey, were fairly predictable. In an October 15, 1889, letter to Richard Maurice Bucke, Whitman reconstructs this daily monotony: "I am sitting here alone \& pretty dull \& heavy — fairly, though, I guess - bowel movementrainy, raw, dark weather - oak wood fire. . . . few visitors lately — a steady shower of autograph applications by mail." 8 A month later, the poet penned essentially the same letter: "Rainy \& dark all day-moderate temperature - ab't as usual with me-bowel action this mn'g-stew'd oysters, Graham bread, apple sauce \& coffee for my $4 \frac{1}{2}$ supper. . . . I am sitting here as usual-no letter mail yesterday \& this forenoon, (except my usual daily stranger's autograph application) — pretty dull with me these days" (Corr., 4:398). Three years before his death, a "steady shower" of daily autograph requests was as commonplace for Whitman as discussing the weather and recording his bowel movements. Other writers may have been more demure in their personal correspondence, but Whitman was in good company when it came to lamenting the rise of the autograph monster.

By the time the first edition of Leaves of Grass was published in 1855, autograph mania was in full force across the United States. As 
the British painter William Powell Frith notes, by mid-century it was inevitable that "all painters, poets, literary men, Church-men-in short, all men who have attained to more or less celebrity" would "become the prey of the autograph-hunter, either in the form of a boy at school, a young lady whose life is made continuous sunshine by the contemplation of your pictures or the study of your delightful poems, or an elderly gentleman who has watched your career with intense interest from its beginning." ${ }^{9}$ For Frith, the passion for autographs was an odd one, but no less intense for ardent collectors: "Each of these applicants, strange to say, avers that he or she will be made happier by the possession of your name on a card or a piece of paper which is enclosed for your signature" (229). The American autograph fiend even gained the reputation of being "more aggressive than his English confrére." 10 While most domestic press coverage of autograph hunting's popularity supported this characterization, the hobby still had its defenders. Appleton's fournal, for instance, recognized in 1870 that the quest for autographs was one of the most "curious manias" to have "taken entire possession of men ... during the nineteenth century," but nonetheless found intrinsic value in the pursuit of celebrity signatures. " "The original writing of a great man's pen - read from the same paper on which the writer's hand rested - is an aid to the imagination, whereby the beholder is enabled to call before his mind's eye the countenance of the illustrious scribe, is assuredly a legitimate object of interest to all intelligent persons." 12

For some, the zealous pursuit of signatures resembled an "epidemic" more than a hobby. "Perhaps, in accordance with the larger charity of this age," one commentator writes in 1892, "it might be best to treat autograph-hunting as a disease rather than a vice. Once the mania has bitten a collector, he is no longer responsible."13 Tennyson was quoted as suggesting "every crime and every vice in the world was connected with the passion for autographs and anecdotes." In his private correspondence, the famed biologist Thomas Henry Huxley, popularly referred to as "Darwin's Bulldog," concurred: "I look upon autographhunters as the progeny of Cain, and treat their letters accordingly." " $[\mathrm{H}]$ eaven forgive you," Huxley cautioned his correspondent, "if you are only an unusually ingenuous specimen of the same race." The entry for "Autographs and Autograph-Hunters" in William Walsh's Handy Book of Literary Curiosities (1892) reported that the letter containing Huxley's warning was recently for sale in London, "a bit of audacity that might have made Cain blush for his progeny" (71). Advertising Huxley's letter for sale was especially brazen, but the garden variety collector met similar contempt. "I hate and despise the mere common autograph-hunter," a writer for The American Magazine asserts, "the noxious being who pesters busy men with a stamped envelope and a 
request that they will write their name, parrot-like, six times over on a piece of paper for him to exchange with other equally feeble and futile collectors." ${ }^{14}$ In his characteristically droll manner, humorist Horace Mayhew urged readers to "beware of your Autograph Hunter. Above all, play not at cards with him, for you cannot tell what that man will turn up who looketh over everybody's hand."15

Taken individually, the average autograph collector was more of a nuisance than anything else, but, if the backlash the practice received seems too harsh, it is worth considering some of the less honorable methods autograph hunters employed to solicit signatures. As one ashamed collector exclaimed in 1893: "To what sin . . . will not an autograph-hunter of the genuine neck-or-nothing type descend!"16 Possessed with the "inane ambition to get as many names as possible," collectors resorted to a number of outlandish ploys. In the spring of 1884, The Atlantic Monthly describes a common ruse involving a correspondent pretending to be interested in replenishing his library; the stranger requests "a detailed list of your works, with the respective dates of their publication, prices, etc." Taken at face value, "this has an air of business," the implication being "that the correspondent, who writes in a brisk, commercial manner, wishes to fill out his collection of your books, or possibly to purchase a complete set in crushed Levant morocco." But, the Atlantic pleads otherwise: "Lay not that flattering inference to thy soul, thou too unworldly dreamer!" ${ }^{17}$ Literary celebrities, especially those "unworldly dreamer[s]" who wrote poetry, were considered easy marks. The sensibility of poets was thought to make them particularly susceptible to the autograph hunter's "diabolical ingenuity" for "getting at the human weaknesses of the famous." 18 Once the poet wrote back, the autograph collector had won.

One of the more widely circulated anecdotes of deception came from the novelist and self-proclaimed autograph fiend, William Black. The following "deadly stratagem" for preying on celebrity victims was attributed to Black's friend, who would write a letter

to each of the persons whose autograph he coveted, describing himself as a ship-owner and asking permission to be allowed to name his next vessel after the particular celebrity he was addressing. It was a fatal trap. Nearly every one fell into it. Even poor old Carlyle had no suspicion, and, in replying to the bogus ship-owner, expressed the hope that the vessel to be named after him might sail into a happier haven than he had ever reached. (Walsh 73)

"Fatal trap[s]" like this made for sensational news; as a result, a survey of late-nineteenth-century periodicals turns up countless examples of autograph hunters going to remarkable lengths-publishing poems under the desired celebrity's name, for example, and writing that poet 
under the auspices of verifying their authorship - to generate a signature. Such tricks evince a shift in the nature of many autograph requests as the century progressed; there is a striking disparity between early letters that convey a reader's fascination with a beloved author and those that simply display a collector's zeal for obtaining a celebrity token.

While Whitman remained guarded against deception, the autograph hunters that offended him most didn't rely on ploys at all-they mailed pre-printed requests instead. And Whitman was not alone in receiving these form letters. An 1883 article in The Literary World reports an author receiving a fill-in-the-blank form that included the following simple, printed message: "Your autograph is respectfully solicited." 19 The standardized request reduced collecting "to a science." There was no "beating about the bush," no "hems and haws, and circumlocutions; no tentative approaches, compliments, apologies, but a straightforward matter-of-fact demand." ${ }^{20}$ In 1891, Traubel records Whitman's reaction to a similar letter from William L. DeLacey of Poughkeepsie, New York. Whitman dismisses DeLacey's note as "the most impertinent autograph request yet"; "Why the fellow absolutely makes a business of it-probably gets the sheets printed by the hundreds" (WWWC, 8:297-298). Whitman, of course, ignored DeLacey's letter, but, had DeLacey been more tactful, he actually stood a good chance of getting the poet's attention. Perhaps if Whitman knew DeLacey was a decorated Civil War veteran who fought in several famous engagements including Battle of the Wilderness and Antietam, or that he later worked as the editor and publisher of the Amenia Times in upstate New York, he may have consented to a modest autograph request as he had done in the past. ${ }^{21}$

Cheaply pre-printed requests like DeLacey's also deprived Whitman of the average autograph request's saving grace: high-quality, reusable paper. Opening an autograph letter and running his pen across the written page, Whitman jokes to Traubel, "those fellows have one virtue - they always use good paper: and on that I manage to do a good deal of my writing" ( $W W W C, 2: 45$ ). Whitman's comment wasn't completely in jest; a number of his surviving manuscripts are written on the back of autograph requests. It's tempting to revisit these poems taking into account their manuscript's proximity to such an obvious marker of literary celebrity. Minnie Vincent's December 11, 1873, note to Whitman, for example, provided the paper for one of the earliest drafts of the poem "Out from Behind This Mask." Whitman crosses out Vincent's letter with one stroke. "I have . . . letters and poems by Bryant, Longfellow, Whittier, S. W. Scott . . Campbell, Montgomery, Bulwer Lytton . . . and many, many more written and signed by their own hands," Vincent writes, "but I have nothing in the autograph of that author whose name is written Walt Whitman-Is it asking too much, if 
you are sufficiently recovered from illness, to request a few lines with your signature to be placed in such good company?"22

It was indeed asking too much, but that didn't stop Whitman from flipping over Vincent's lined paper and drafting "a few lines" for a poem he was tentatively titling "Behind this mask," conceived of at the time as "The poem of the head the face." Of course, "Out from Behind This Mask" (subtitled "To Confront a Portrait") is most commonly read in correspondence with William J. Linton's engraving of the poet included in the Centennial edition of Leaves of Grass, but Vincent's letter offers another basis for comparison-the writing literally behind Whitman's poetry manuscript. On the back of Vincent's letter there is no mention of the "burin'd eyes" of Linton's engraving nor its depiction of Whitman's face, his "heart's geography's map" (LG 1881, 296). In its published form, the poem would ask readers to consider what lay behind the poet's "rough-cut mask," but, in manuscript-without the accompanying engraving as a visual referent- "this mask - this curtain," "This map + chart - this surface" not only describes Whitman's unseen face but also calls attention to the scene of inscription, the "surface" of the paper itself. Whitman's fame-the celebrity created by and reflected in the autograph request - emerges as yet another mask behind which the poet's "real book" is hidden. To argue for a strictly determined relationship between Whitman's manuscripts and the autograph requests some are written on would be to go too far, but the possibility of such correspondence exists. Regardless, it is worth remembering that at the very least the autograph hunter played a passive role in the composition of a number of Whitman's postbellum poems.

Just as Whitman transformed annoying letters into useful scrap paper, the poet-beginning in the late 1870s - developed a strategy for dealing with autograph hunters that attempted to turn the burdensome requests into charitable donations. When he was feeling, in the words of Traubel, "terribly persecuted for autographs," Whitman would sometimes be "driven to an old trick." "I used to put portraits containing my autograph with the folks out at the Children's Home," he tells Traubel, "turning all applications over to the Home, which asked a dollar apiece for the pictures, and, often, got it" ( $W W W C, 2: 95)$. Coverage of Whitman's stunt cropped up in papers across the country. The St. Louis Globe-Democrat, for example, reported in 1876 that "Walt Whitman satisfies the importunate autograph-hunters by informing them that his photograph, with signature attached, can be obtained on sending $\$ 1$ to the Matron of the Orphans' Home at Camden. The proceeds are entirely for the benefit of the orphans."23

Not only did Whitman intermittently forward his autograph mail to the Orphans' Home, but he would also occasionally request a donation 
on their behalf when autograph collectors visited his Camden home. In Ivory Apes and Peacocks, James Huneker, the famed music critic, details how he obtained Whitman's signature, "written in large, clumsy letters," on those terms during the summer of 1877. Huneker, who kept the autograph pasted inside a copy of the 1867 Leaves of Grass, writes: "I value this autograph, because Walt gave it to me; rather I paid him for it, the proceeds, two dollars (I think that was the amount), going to some asylum in Camden." ${ }^{24}$ Huneker's account strains to project a sense of intimacy with Whitman-referring to the poet as "Walt," for instance - and stumbles when confronting the reality that the coveted signature was the result of a financial transaction. "I begged for an autograph," Huneker admits; "He told me of his interest in a certain asylum or hospital, whose name has gone clean out of my mind, and I paid my few dollars for the treasured signature" (24). All the money Whitman raised through these autographed portraits went to charity, but the extra attention surely offered residual promotional benefits. The donations Whitman's celebrity inspired did not provide direct financial relief to the poet, but his well-publicized attempts to keep autograph hunters at bay perpetuated an image of Whitman as a sought-after commodity.

No doubt aided by the coverage his charitable donations received, Whitman's attitude toward the nation's legions of autograph hunters became common knowledge. In a parody titled "His Warning to Autograph-Hunters," Henry Cuyler Bunner-the long-time editor of the popular American humor journal Puck, operating under the pseudonym V. Hugo Dusenbury - captured Whitman's public disgust with the autograph monster. Following parodies of Longfellow, Swinburne, and Sidney Lanier that burlesque each poet's style via fictionalized warnings to collectors, Bunner concludes with Whitman's reply to a "polite request for an autograph":

I like you. I like your impudence. I like your cold, hard gall, your nerve, the cheek of you.

You come cavorting about me as if you were my side-partner, as if you had slept under the same blanket with me, as if you had bitten off the same plug.

You ask me for my autograph, for my sentiments.

This is my autograph. These are my sentiments.

You are a lop-ear'd, cross-ey'd, blue-nos'd son of impudence, Americano, indecent, refrigerative of cheek, daisy-like, fresh.

That is my autograph. Those are my sentiments. Take them. Go to blazes with them. ${ }^{25}$

Couched in Whitmanian verse, Bunner's piece manages to capture the irony of Whitman's dismissal of his anonymous admirers. By appropriating the poetic persona of "Walt Whitman," Bunner lampoons 


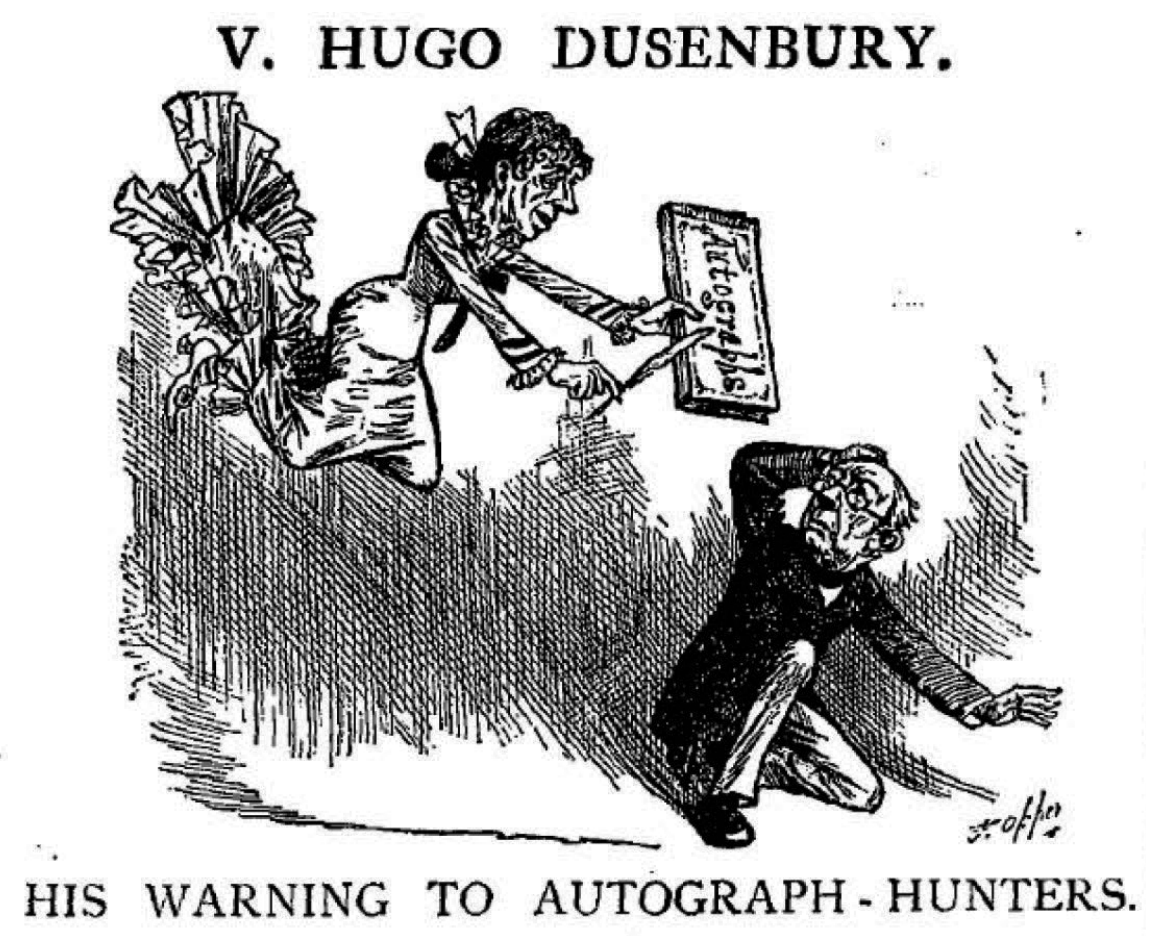

Figure 1. "His Warning to Autograph-Hunters," Puck (November 10, 1880), 156.

both the presumed familiarity autograph hunters convey through their correspondence and the strains in Leaves of Grass - such as Whitman's celebration of anonymous urban affection and the intimate physical relationship between author and reader his text enacts- that seem to provoke such behavior. Where the poetry of Leaves of Grass might welcome the thought of "cavorting" with "Walt Whitman" as if you were his "side-partner," the poet worked to separate for autograph-hunters the intimate invitations his poetry constructed from the reality of his private life.

Bunner's parody is accompanied by an illustration of an autograph hunter hovering above a male author (Figure 1). The overt gendering of the autograph fiend throughout Puck's parody emphasizes the threat of emasculation posed by the (female) collector. In relegating the hobby to the feminized domestic sphere, Bunner establishes an opposition between the frivolous female collector and the intellectual male artist that she haunts. The illustration further emphasizes this dynamic. Floating above (or jumping down onto) the male author, the pictured collector has assumed a dominant position, supposedly unbecoming of 
her sex-it is she who holds the paper and pen, the proper tools of the writer. Her appearance, however, is monstrous; her face is wrinkled and deflated, rendering her youthful dress grotesque. "I share with you the feelings of horror with which you view the growing craze for autographhunting," Bunner prefaces his parody; "It is a bold, bad, unprincipled mania which is seizing frail and susceptible womanhood in its deadly grasp, and transforming the sweetest and subtlest work of nature; the light and perfume of creation, into a ravening monster." The monster's ideal prey is the "professional poet." While Bunner allows that there "are other classes [of celebrities] who may be approached with safety," a man "who has to sling inspiration for his living has no time to waste in writing memorials for posterity, to be confided to the care of monomaniac young females."

To be sure, there were many female autograph hunters-Whitman was approached by a number of them at home and through the mail for his signature "and a sentiment"-but Bunner's parody oversimplifies the presumed demographics of the American collector, relying heavily on deeply embedded cultural associations linking women and hysteria. ${ }^{26}$ Such culturally hard-wired assumptions would dictate that the "sweetest and subtlest work of nature" was more likely to fall victim to the "unprincipled mania" of autograph hunting. Bunner genders as male the commercial role of the writer, feminizing the force that threatens to destabilize that professional identity by imposing the demands of the domestic sphere, the only proper realm for such an impractical hobby. Puck creates an exaggerated "ravening monster" for comedic effect, but the fear that autograph hunters could dramatically impact a writer's productivity was common.

Authors who were reluctant to deny signature requests become points of reference for critics wary of the collector's impact on American literary production. In his journals, Longfellow "plaintively mentions the necessity of complying with thirty or forty requests" on an average day; according to the poet's personal records, on January 9, 1857, that number doubled: "Today I wrote, sealed, and dictated seventy autographs." 27 Publicly, Longfellow maintained that he enjoyed performing "this little favor," telling one visitor: "It is so little to do, to write [my] name on a card; and if I didn't do it some boy or girl might be looking, day by day, for the postman and be disappointed. I only wish I could write my name better for them." 28 Whittier met the demand for his signature with comparable generosity and stoicism. In June 1891, Whitman was sent an elaborate, leather-bound autograph album by Samuel B. Foster, a lawyer and amateur poet from Chicago. ${ }^{29}$ The book was filled with celebrity autographs, including Whittier's. The thought of "the gentle Whittier" being hounded for his signature incensed Whit- 
man: "It is a horrible practice — a pest—yes, pestilential-I hate to think of it: days and days, nothing but applications, applications! Think of the gentle Whittier! He must be the most pestered of all-yet never a word-a public word!" With no stamp or paper to pilfer, Whitman provided "a few lines" for Foster, "but all under protest," exclaiming "damn the crowd! I have to return the book . . . might as well put in a word" ( $W W W C, 8: 267)$. Whittier had seen more brazen collectors than Foster, though. According to one account, he was once mailed over eighty cards from an "enterprising young woman" soliciting his signature for herself and friends - it is one of the few times on record that Whittier declined to respond. ${ }^{30}$

With popular authors like Longfellow and Whittier otherwise willing to comply with autograph requests so faithfully, collectors were emboldened to view the practice as the duty of celebrated writers. The Atlantic ventriloquized this prevailing attitude in 1884: "It seems such an easy thing for an author to give his autograph! He must be a crossgrained, unaccommodating person, indeed, who refuses to scratch his name on a bit of cardboard or a slip of paper, when it would give somebody so much pleasure!" However, the Atlantic concludes, the autograph hunter "has made it heavy work for the author who is unfortunate enough . . . to be popular." In this earlier and more subtle variation of Bunner's anxiety, the threat to the American male artist is again reiterated: "Every mail adds up to his reproachful pile of unanswered letters. If he is not cautious, he will find himself in correspondence with so exigeant a crowd of persons that he will have no leisure left to attend to his proper profession." 31 Through anxious commentary like this, we witness concerns regarding the nature of literary celebrity rise to the surface. As modern forms of publicity and promotion develop, the author becomes further removed from a renown based on intellectual labor and moves closer to a celebrity constructed entirely of cultural recognition, a fame built on the repeated circulation, not of a writer's literary works, but of his or her name and personality.

Fears of this emerging form of modern renown become projected onto the autograph hunter, who is characterized as the harbinger of a celebrity culture that relegates the creation of literary texts to an avocation. Critics regularly suggested authors should begin charging for their autographs, imagining promotional scenarios which anticipate twenty-first-century networks of fame. As Glass remarks, the "collectability of autographs encouraged a sense that authorial identities could literally be bought and sold" (42). One writer playfully predicts that "by the end of the twentieth century, when the full business possibilities of autograph writing are realized, all . . a authors will be millionaires." A budget is proposed to subsist entirely on autograph revenue: 
If an author would work up a regular business of two hundred cash-down signatures a week he would, as the world goes, be doing very well for himself. That would bring in $\$ 500$ a week, or $\$ 25,000$ a year, allowing him two weeks vacation. An author without extravagant habits ought to be able to lay aside something for a rainy day on such an income. What he received from his ordinary, every-day literary writing he could use for pin-money and to buy ink with for his autograph writing. ${ }^{32}$

Whitman's efforts to promote his books by including his autograph don't fulfill the scenario outlined above; yet, as I will demonstrate, without entirely divorcing his signature from his literary work, Whitman still capitalizes on the autograph's "business possibilities."

Part of what made Whitman a suitable candidate for this kind of marketing experiment was his notorious scorn for signature hunters. The manner in which professional authors managed the circulation of their autographs could have a dramatic impact on a manuscript's value to collectors. When considering the commercial weight of a given signature, collectors evaluated both the writer's "relative . . . celebrity" and "the question of rarity." If an author had been "a willing victim to the insatiate autograph hunter," too "liberal of epistolary favors with those who offer his chirographic confidences in the public mart," the basic principles of supply and demand dictated a lower price. Longfellow's seventy signatures in a day were legendary, but that kind of generosity created "a serious depression in the value of his pen-productions by "flooding the market." 33 Whitman never took an active interest in how much his autograph (divorced from his literary work) sold for, but the tight control he exerted over his signature certainly made it more valuable. "To the autograph collector Walt Whitman is a well-known terror," the Philadelphia Times wrote, "and his persistent refusals of his signature make such few letters as he writes the more valuable in the open market" ( $W W W C, 4: 164$ ). In a response to the rise of the autograph hunter, Whitman began to limit his handwritten correspondence with strangers considerably, unless, that is, they purchased one of his books. Authors struggled to strike the right chord with collectors seeking their signature; after all, autograph hunters, though bothersome, were also potential literary consumers. The question remained how to satisfy simultaneously the needs of the author and the desire of the collector.

Reluctant to ignore autograph hunters outright, but unwilling to fall victim to any of their infamous tricks, authors like Twain and William Dean Howells introduced the use of printed responses to requests for their signature. These documents offered no coveted signature, no precious trace of authorial presence-their emphasis was on protecting the livelihood of the literary professional which depended on, first and foremost, selling books. Twain's response to autograph hunters does not overtly demand cash in exchange for his signature; instead, through 
a series of humorous analogies, he defines the author's autograph as a "specimen of his trade," a valuable commodity not to be surrendered free of charge:

I hope I shall not offend you; I shall certainly say nothing with the intention to offend you. I must explain myself, however, and I will do it as kindly as I can. What you ask me to do I am asked to do as often as one-half dozen times a week. Three hundred letters a year! One's impulse is to freely consent, but one's time and necessary occupations will not permit it. There is no way but to decline in all cases, making no exception; and I wish to call your attention to a thing which has probably not occurred to you, and that is this: that no man takes pleasure in exercising his trade as a pastime. Writing is my trade, and I exercise it only when I am obliged to. You might make your request of a doctor, or a builder, or a sculptor, and there would be no impropriety in it, but if you asked either for a specimen of his trade, his handiwork, he would be justified in rising to a point of order. It would never be fair to ask a doctor for one of his corpses to remember him by. (Walsh 73$)^{34}$

Twain's sarcasm might have been disarming enough to assuage a disgruntled collector, but he leaves no doubt that time and money "will not permit" him to comply with such requests.

Howells's printed response takes a different approach. Whereas Twain positions the free autograph as a direct threat to his trade, Howells introduces a new strategy, one which embraces the autograph in the hope of creating a closer correlation between book sales and signatures in circulation. Plagued by a reputation of being "very gentle and yielding" to autograph hunters, Howells proposes a "sharp change" to his behavior (Johnson 169). In an interview originally published in the New York Sun, Howells unveils his plan, which would soon be outlined in a printed circular and mailed out in reply to autograph requests:

The requests for my autograph have of late become so burdensome that I am obliged either to refuse all or to make some sort of limitation. Every author must have an uneasy fear that his signature is "collected" at times like postage stamps, and at times "traded" among the collectors for other signatures. That would not matter so much if the applicants were always able to spell his name, or were apparently acquainted with his work or interested in it. . . I propose, therefore, to give my name hereafter only to such askers as can furnish me proof by intelligent comment upon it that they have read some book of mine. If they can inclose a bookseller's certificate that they have bought the book, their case will be very strengthened; but I do not insist upon this. In all instances a card and stamped and directed envelope must be inclosed. I will never "add a sentiment" except in the case of applicants who can give me proof that they have read all my books, now some thirty or forty in number. (Johnson 170)

Collectors are presented with several tiers of acceptable requests, each predicated on a familiarity with Howells's literary work-proof of 
purchase being the strongest evidence thereof-and the inclusion of a self-addressed, stamped envelope. Only on the rarest occasion would Howells provide the dreaded personalized "sentiment." "If the scheme works well and increases sales," The Bookman predicts, "other authors will naturally adopt a similar course, and the autograph hunter will be regarded in a new light by our men of letters" (Johnson 170). Implemented three years after Whitman's death, Howells's cautious embrace of the autograph's promotional potential did indeed foreshadow an even greater modernization in literary advertising - with its soon to be obligatory book tours and public signings-during the upcoming decades.

Once Whitman started selling signed editions of his poetry-a practice that, as I will examine, started with the 1876 Centennial edition of Leaves of Grass and continued until the 1889 reprinting of the Osgood edition - he too began to take advantage of printed advertisements to translate the demands of autograph hunters directly into the sale of books. This was the case when J.W. Bartlett wrote to Whitman in June of 1884 asking for his signature. What Bartlett received in reply was a small printed card advertising the 1882 Author's Edition of Leaves of Grass, a three-dollar book which Whitman was willing to sign. Had Bartlett solely been interested in Whitman's signature, the poet's promotional card would have been thoroughly disappointing. Bartlett, however, was not merely an autograph monster-he was willing to purchase a copy of Leaves of Grass and promptly mailed Whitman a check. In return he received not only an autographed edition, but also a signed, handwritten note from Whitman thanking him and asking Bartlett to write the poet again to notify him of the book's receipt (Corr., 3:372).

The full story of Whitman's use of his signature as a promotional device dates back at least to 1868 when the poet's autograph first appeared in print as a facsimile in the British edition of Poems by Walt Whitman edited by William Michael Rossetti and published by John Camden Hotten. Rossetti was an avid collector of autograph manuscripts and signatures - he later carried on an extended correspondence on the subject with Charles Aldrich, a former member of the Iowa House of Representatives and a dedicated Whitman collector-so it is fitting that he would be linked to the first published version of Whitman's signature. ${ }^{35}$ In fact, the facsimile included in Poems by Walt Whitman still carries a trace of its origin in correspondence (perhaps reproduced from one of Whitman's many letters to Rossetti himself) — a small comma after the ' $n$ ' is retained, the only instance of Whitman's signature appearing this way in his books. The autograph is printed underneath a truncated version of the 1855 Leaves of Grass steel engraving.

Hotten advertised the volume widely, billing it as a companion piece "uniform with" Algernon Charles Swinburne's controversial Poems and 
Ballads. Before Whitman had even seen a copy of the book, Rossetti mailed him an early advertisement published in The Athenaeum which prominently mentions (as all of Hotten's notices would) the "Portrait and Autograph" to be included. ${ }^{36}$ One reviewer called the book "an excellent index to the writings of a man who cannot be overlooked," but Whitman's signature and the accompanying portrait functioned as their own index of the poet. ${ }^{37}$ In one of his essays on autography, Edgar Allan Poe places portraiture and signature side-by-side as indexical models of their subject's personality: "Next to the person of a distinguished man-of-letters, we desire to see his portrait-next to his portrait, his autograph," Poe writes; "In the latter, especially, there is something which seems to bring him before us in his true idiosyncrasy-in his character of scribe." ${ }^{38}$ In The Philosophy of Handwriting, John H. Ingram goes further to declare the autograph's superiority as an index of celebrity personality, claiming "an autograph has this advantage over a portrait, it must be faithful, which a portrait rarely is." ${ }^{39}$ By providing readers with two indexes of Whitman alongside one another for the first time, Hotten helped create for English readers the illusion of personal contact with America's unruly bard..$^{40}$

Whitman had virtually no say in the material design of the Rossetti edition - there is no record of whether or not he even knew Hotten would include his autograph in the volume-but the prominently displayed and promoted facsimile signature may have inspired Whitman's truly original experiment celebrating the United States Centennial in 1876. The so-called Centennial (or Author's) edition of 1876-a reprinting of the fifth edition of Leaves of Grass supplemented with two portraits and some other minor additions-was the first volume in which Whitman systematically included his actual autograph (Figure 2). "It may interest some to know," one reviewer writes, "that the volumes of this 1876 edition . . . have each the author's physical touch and magnetism ... [each] has been handled by him, contains his signature, and the photograph and pictures put in by his own hands." ${ }^{\text {11 }}$ With the Centennial edition, Whitman capitalized on the nation's hunger for autographs in a way no author had done before.

Signing a book, in and of itself, wasn't a novel concept during the nineteenth century. Inscribed presentation copies and gifts were, as Leon Jackson has recently argued, fundamental components in a set of fluid "authorial economies"-circuits of exchange dealing in economic, cultural, social, and symbolic capital. ${ }^{42}$ Where Whitman differs fundamentally from his contemporaries, however, is in his use of the autograph not only as an authenticating gesture - an imprimatur-but also, and more importantly, as a preconceived marketing device. Whitman continued to inscribe books for friends and families his 


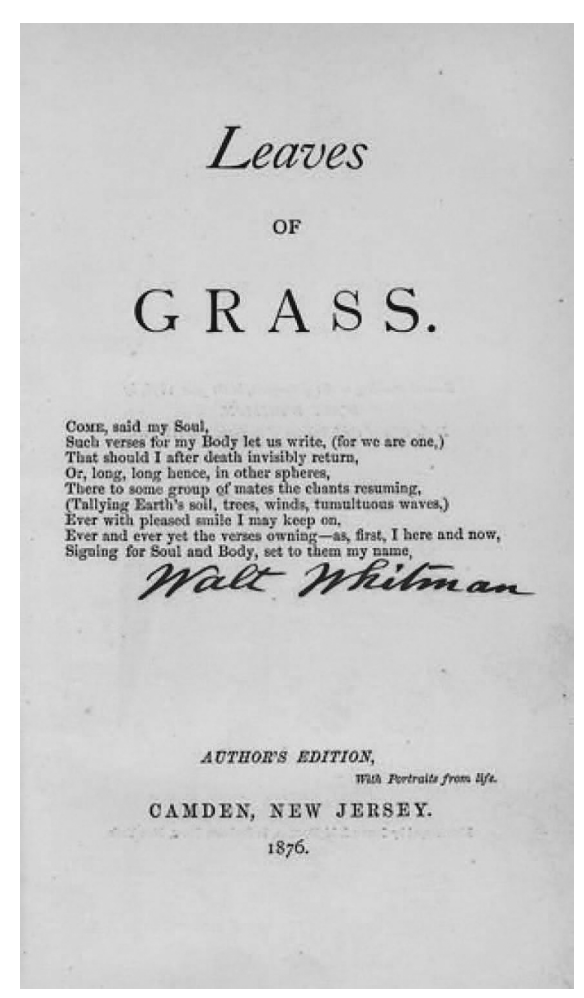

Figure 2. Autographed title-page of the third printing of the fifth edition of Leaves of Grass (1876).

entire life - this activity becomes especially labored closer to the poet's death - but only on a few distinct occasions did he plan and promote volumes that included his signature no matter who was purchasing or receiving them as a gift. In this regard, the Centennial edition of Leaves of Grass and its companion volume, Two Rivulets, are landmarks in the development of literary promotion; for perhaps the first time, an author's autograph was utilized as an integrated component in the design and advertisement of a literary work. The 1876 printing of Leaves of Grass and Two Rivulets was promoted as the "Autograph and Portrait Edition of Walt Whitman's Complete Works"-a manicule at the bottom of one advertisement points potential consumers to this fact: “ Autograph in every Volume above." $"$ 33

What is most striking about Whitman's signature in this edition and the title-page as a whole-a basic format he would reuse in Complete Poems $\mathcal{E}$ Prose (1888) and with a facsimile for the deathbed edition (1892) - is the consciously designed interplay of text and script 
involving Whitman's writing of an epigraph poem especially for the titlepage: "Ever and ever yet the verses owning — as, first, I here and now, / Signing for Soul and Body, set to them my name,"- the concluding comma announcing the arrival of Whitman's autograph, a marker of ownership, witness, and transcendent presence. In that comma-an open punctuation mark, not the full-stop of a period-is the print indication of Whitman's preplanned marketing scheme. The design of the book and the punctuation of the prefatory poem expect and invite Whitman's name - the autograph was intended when the type was set. Others have noted the relationship between Whitman's participial verbs (owning, signing) and the performance of presentness his autograph inscribes, but what is most innovative in Whitman's title-page is the way the print reveals itself as a prior act which anticipates its author's signature. That is the truly new promotional device: the planned and fully integrated autograph, one that uniquely merges handwriting and print, what Meredith L. McGill calls "the modes . . of composition and reception." ${ }^{44}$

Complete Poems E Prose (1888) is the second of Whitman's books to include his signature as a promotional feature. Its title-page virtually replicates the Centennial edition: Whitman's prefatory poem "Come, said my Soul," ending with a comma and followed by the poet's autograph. In his introduction to the volume, Whitman packages his signature not as a marketing device, but as the endorsement of a will, with his readers the designated heirs of the literary work it authenticates. "I wanted to leave something markedly personal," Whitman writes: "I have put my name with pen and ink with my own hand in the present volume. And from engraved or photographed portraits, taken from life, I have selected some, of different stages, which please me best, (or at any rate displease me least), and bequeath them at a venture to you, reader, with my love." Whitman's autograph in the 1889 birthday edition of Leaves of Grass is positioned in a similar way; following the poet's assertion that the "volume is more A PERSON than a book," he concludes: "for testimony to all, (and good measure,) I here with pen and ink append my name:" Whitman's now familiar signature impressed one reviewer of Complete Poems $\mathcal{E}$ Prose who called it "strikingly firm and bold," noting that "the paralysis that afflicts the author has not affected his firm hand." 45

Not everyone was convinced that Whitman's "firm hand" produced the signature in each volume. In a conversation with Traubel about an exceptionally skeptical book buyer, we find one of the only times Whitman directly refers to his autograph as a promotional device. The method Whitman used for integrating his signature with the Centennial edition, Complete Poems $\mathcal{E}$ Prose, and eventually the 1889 birthday 
edition of Leaves of Grass involves a pre-planned play between text and script most apparent in the punctuation preceding his signature-a comma in 1876 and 1888 and a colon in 1889 . Unlike any of his other books (many of which he autographed for friends), had Whitman not signed these title-pages it would be obvious a signature was missing. By including his signature as, essentially, part of the printed text, Whitman subdues an overt promotional gesture by transforming his signed name into part of a poetic work. In other words, Whitman did a nice job of obscuring that fact that the main reason he was signing his books was to sell those books. As Traubel reports, though, Whitman's clever marketing device was not enough for one stubborn customer:

McKay yesterday had a customer for the big book. He looked at the signature. "It's not genuine," he said. McKay assured him it was, but the man was not convinced. "Get him to sign his name on some other page, then I'll buy the book," he said. Would W. do it? I asked him this yesterday. He laughed a little: "I don't know whether I want to or not: I want to sell the book: that's a temptation: I'd do anything honest to sell books." $\mathrm{He}$ finally said: "Bring the book over." I did so today. He had a good laugh over it. "I wonder whether I should get a notary to affirm the second signature?" Then: "Tell Dave we'll do this this time but can't consent to make a practice of it: we are anxious to sell the books, God knows, but only to those who will accept the authenticity of the signature as it stands: this fellow must be one of the skeptical sort: a confirmed semi-petrified business man: one of the doubters of everybody: one who throws cold water on people-is always expecting to be swindled, always being ready himself to swindle. It's a hell of a habit to get into. ( $W W W C, 4: 396)$

Whitman's willingness to sign the book for a second time underscores both just how "anxious" he was to make a sale and just how new the poet's "honest" marketing device was for literary consumers, even after the Centennial edition. This twice-autographed copy of Complete Poems $\mathcal{E}$ Prose represents an author and his readers cautiously entering new promotional territory, unmarked terrain on which Whitman was writing his name.

The 1889 edition of Leaves of Grass issued in honor of the poet's seventieth birthday - what was actually the fourteenth printing of the 1881 edition, now given, as Ed Folsom notes, "the look and feel of a Bible" - was the last of Whitman's publications to include an autograph in each copy. ${ }^{46}$ Even with the book's relatively limited print run, Whitman struggled through his signatures. After a long debate with his publisher David McKay, Whitman opted not to include his actual autograph as a planned element within any of the 1892 copies of Leaves of Grass. As late as 1891, however, he was still taken with the promotional potential of his autograph, suggesting to Traubel and McKay that two versions of his final Leaves of Grass should be published: a cheap edition to include a facsimile signature and a more expensive 


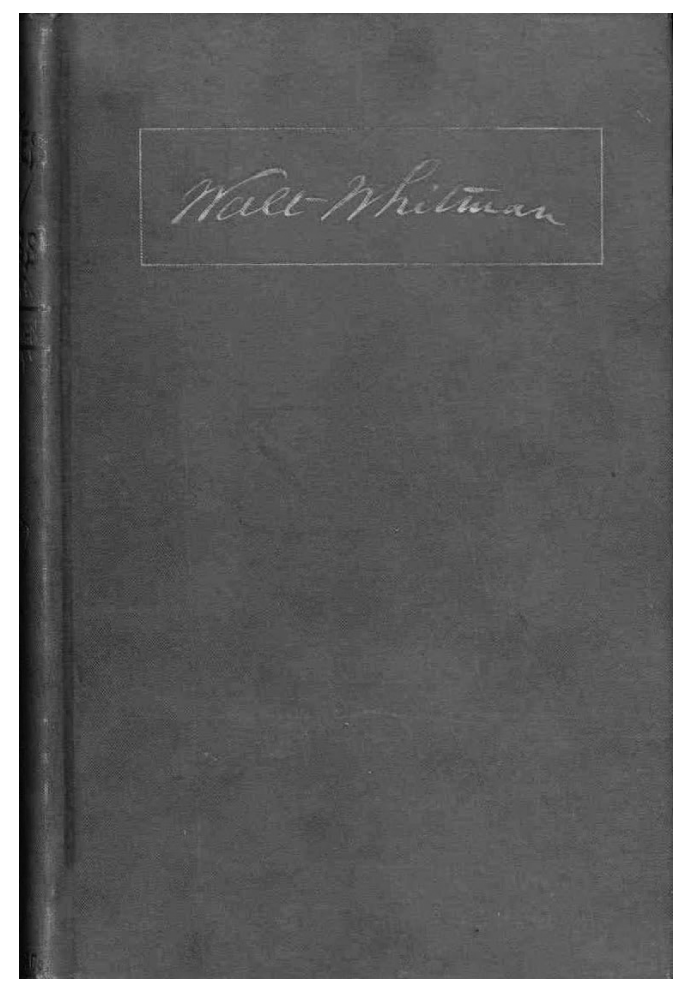

Figure 3. Front cover of the 1881 Leaves of Grass.

version with his real autograph ( $W W W C, 8: 547)$. As McKay resisted the idea of a one-dollar edition of Leaves of Grass, Whitman became less interested in including his signature, eventually conceding, "I do not insist upon actual autograph: perhaps the facsimile would serve for all" (WWWC, 9:10). And so the deathbed edition of Leaves of Grass features a facsimile of Whitman's signature on the title-page. Though he liked the idea of a slightly higher priced, autographed edition, Whitman ultimately retreated into a feigned lack of interest. "About the actual and facsimile autographs," he tells Traubel, "I don't care much or anything" (WWWC, 9:58).

Whitman's signature - either as a facsimile or written by hand - appears inside the poet's books far fewer times than it does printed on the cover. James R. Osgood's design for the 1881 Leaves of Grass marks the first appearance of Whitman's signature on the exterior of a book (Figure 3 ). While the spine of the Osgood edition features a playful revision of Whitman's butterfly manicule from the 1860 Leaves of Grass, the front cover is staid and minimalist. The simple presentation is remarkably 


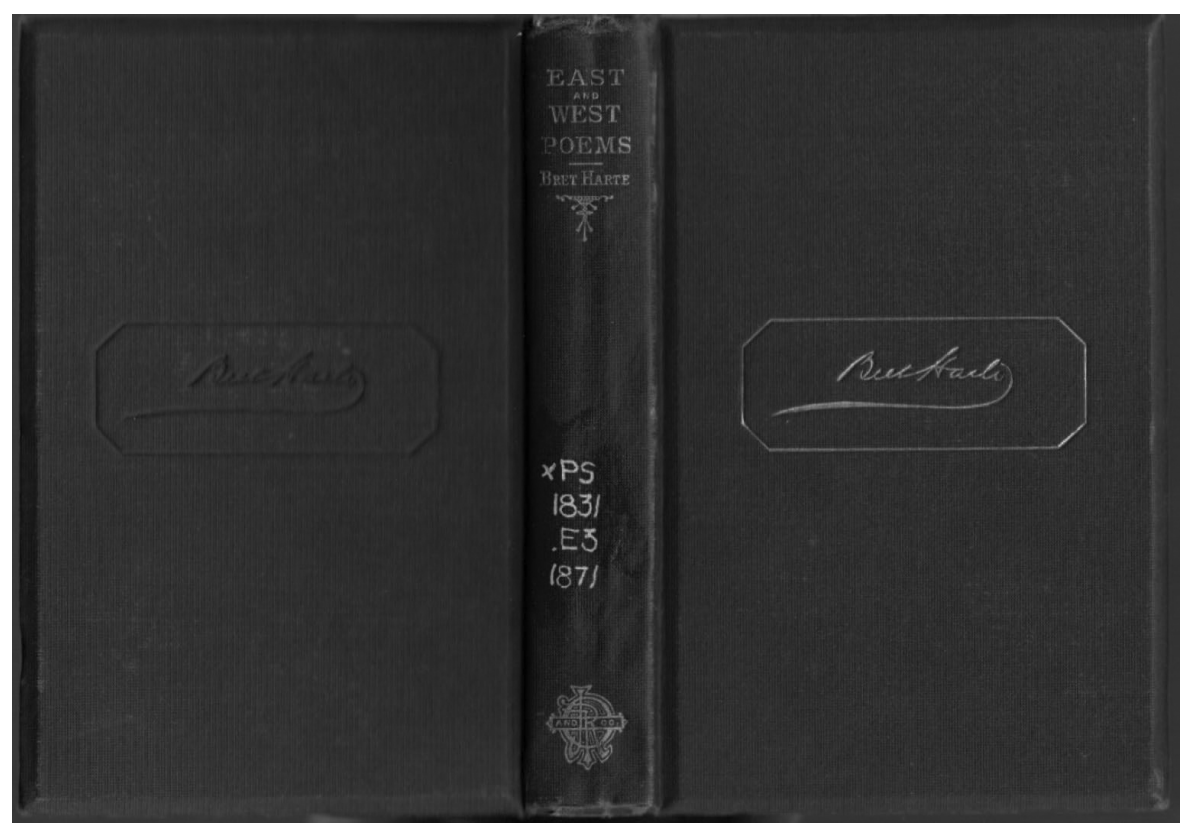

Figure 4. Binding of Bret Harte's East and West Poems (1871).

similar to a number of books Osgood published during the 1870s; the rectangular rule and facsimile autograph - though used by other publishers - was a particular favorite of Osgood's. Whitman would return to the gold-stamped signature as a prominent component of his cover designs after 1881, but its first appearance resulted from a combination of his desire to create a book without "sensationalism or luxury" and his publisher's apparent fondness for that style (Corr., 3:226). For example, Bret Harte, one of the firm's highest paid authors, published two volumes of poetry with Osgood in 1871-Poems and East and West Poems - which share a design that is nearly identical with one another and that clearly anticipates Whitman's volume a decade later (Figure 4). Harte's tiny signature appears stamped in gold on the front cover and blind-stamped on the back. The poet John Hay, a good friend of Whitman's, likewise published two volumes with Osgood in 1871-Castilian Days and Pike County Ballads - which share the exact same conservative design. These sorts of gold-stamped signatures emphasize the celebrity status of the authors they represent, often replacing the title of a book with the author's autograph instead. The distinctive style becomes a material representation of literary celebrity in that the author's identity "as a person" supersedes his or her literary work. ${ }^{47}$ For a poet like Hay, whose literary reputation declined sharply after his death, the stature 
his facsimile signature signified was short-lived. ${ }^{48}$ Harte, who entered into a contract with Osgood for ten thousand dollars at the height of his career in 1871, enjoyed a more sustained fame despite the fact his literary production faltered during the $1880 \mathrm{~s}$. But, for readers at the time, both authors-like Whitman-were marketable names; the material design of their books, though understated, mirrored their celebrity status.

Whitman's conservative appearance in the Osgood edition and thereafter is even more astounding when we consider the "creativity and excesses" of contemporary cloth covers. ${ }^{49}$ As Richard Minsky observes, in the 1870s "book cover art in the United States entered a Golden Age that lasted more than fifty years"- - some publishers went as far as commissioning "painters, architects, and stained glass designers to create covers that would grab the eyes of bookstore browsers." ${ }^{50}$ Spurred on by non-literary works - how-to manuals, parlor books, etc. - publishers were "sweeping away the niceties of taste and propriety, transforming the subject matter of the cover stamp," which was often "pictorial, specific, [and] expressive of the nature of the book." ${ }^{51}$ Even Osgood was capable of more whimsical covers for literary texts. The translation of Jules Verne's Doctor Ox (1874), for example, continues to feature the goldstamped facsimile signature but captures some of its subject's innovative spirit with a pictorial design (Figure 5). In this regard, the designs of Whitman's postbellum books are quite cautious - the 1860 edition of Leaves of Grass remained the pinnacle of Whitman's typographical experimentation. What Whitman gained through a conservative, yet more focused design, however, was true brand unity: he could place his autograph on the cover of every book he published and book buyers would recognize it immediately; his signature functioned as a marker "both of originality and standardization" (McGill 66). His name and his commercial image became one and the same.

Whitman's innovations in branding through the 1870 s were substantial, and his innovations with his autograph signature were groundbreaking. However, by the Osgood edition, the use of facsimile signatures on the cover of literary works - one of the few branding mechanisms publishers willingly borrowed from other commercial industries where signatures regularly functioned as central trademark symbols - had become commonplace. The design of the 1881 Leaves of Grass blends in with the volumes of Harte, Hay, and countless other established authors. But, for Whitman at this time, that was precisely the point. Early in his career, he relied on brash branding techniques that made him stand out, got his book talked about, caused a stir. At the end of his life though, he was happy to see his brand blending in with those of other well-known writers. With the Osgood imprimatur, Whitman had made it - he could bask in the idea that his brand, now 


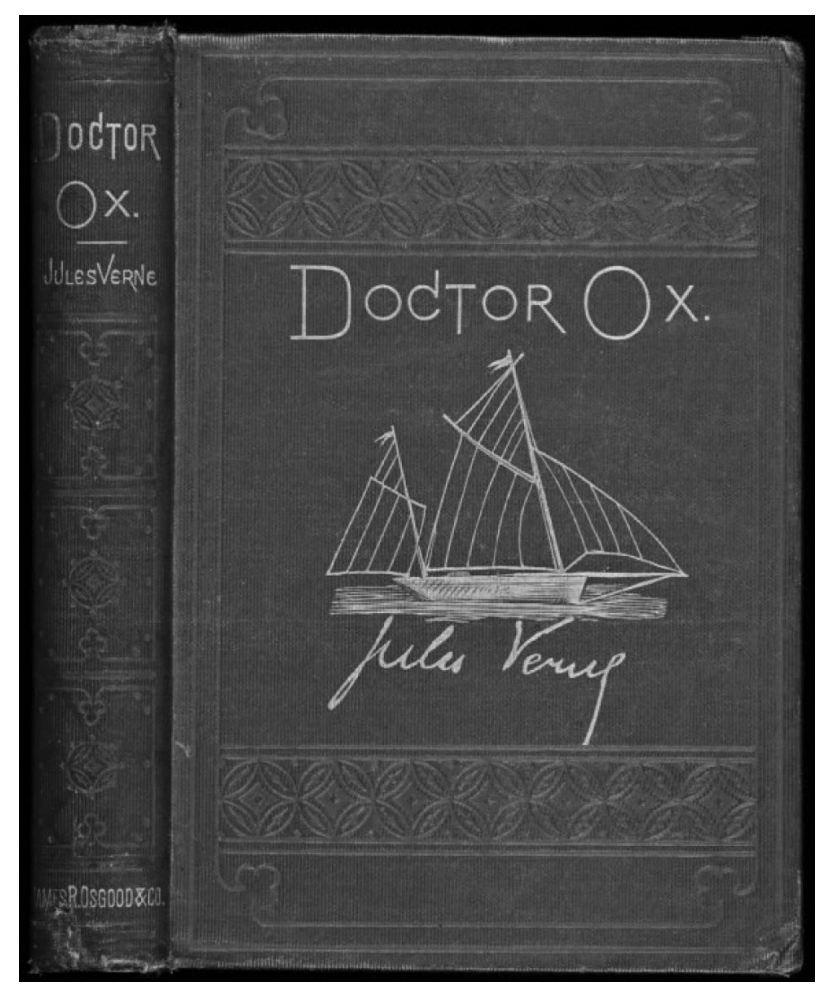

Figure 5. Front cover of Jules Verne's Doctor Ox (1873)

represented through his signature, was one with other successful authors. Even though Whitman's association with Osgood's mainstream reputation was short-lived-by the spring of 1882 Osgood had cut ties with Whitman following the New England Society for the Suppression of Vice's campaign against Leaves of Grass - the poet retained Osgood's cover design and continued to make his book look "respectable" with his new publisher, Rees Welsh \& Co., while sales of his poetry took off because of the obscenity controversy.

When David McKay took over for Welsh later in 1882, he and Whitman continued to utilize the conservative design throughout the poet's final books. Whitman's facsimile autograph appears gold-stamped on November Boughs (1888), the 1889 birthday edition of Leaves of Grass, Gems from Walt Whitman (1889), Good-Bye My Fancy (1891), and the 1892 deathbed edition of Leaves of Grass. Whitman's signature had evolved from a facsimile tucked inside a foreign edition of the poet's work to the central visual marker of the Whitman brand. Nowhere is this clearer than with the design of the 1889 birthday edition of Leaves. 


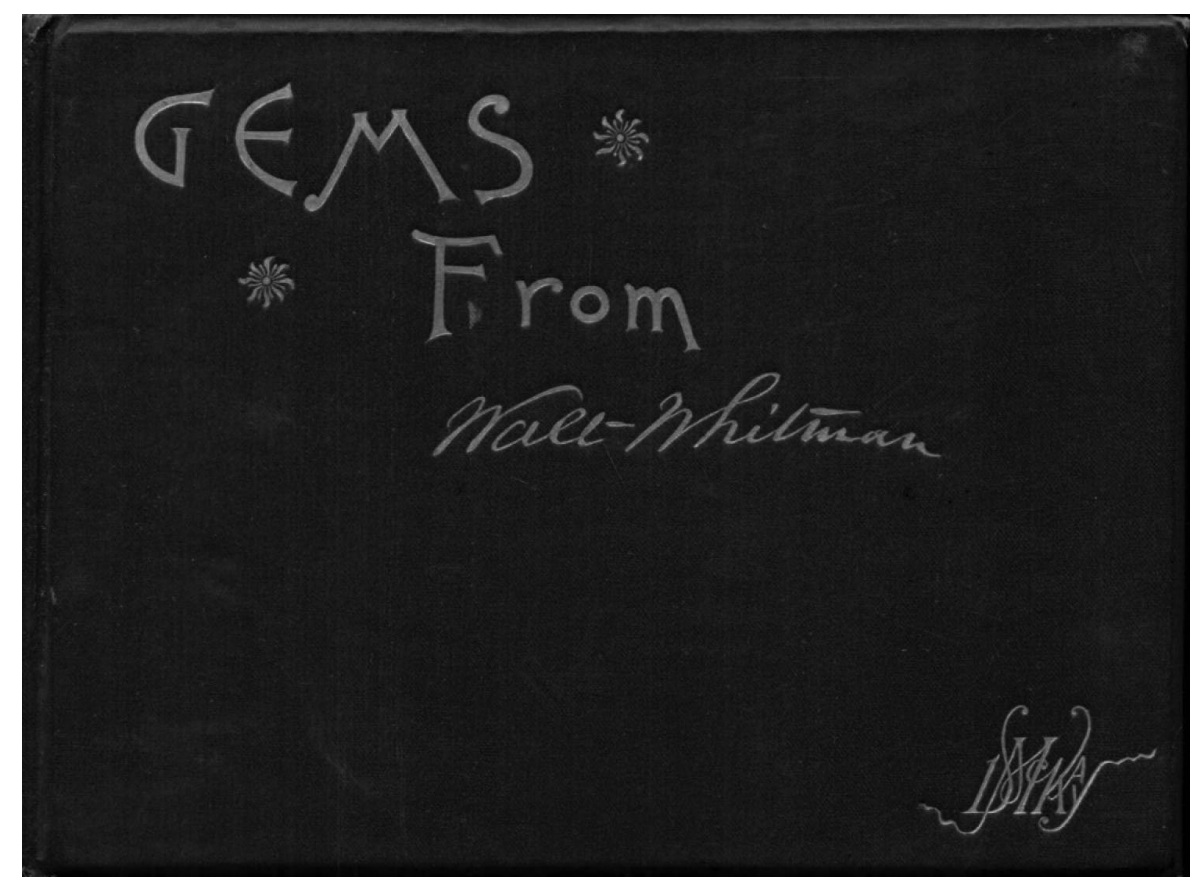

Figure 6. Front cover of Gems from Walt Whitman (1889).

Whitman's signature appears in or on that volume three times; in addition to the author's actual autograph on the title-page, the signature is gold-stamped on both the front cover and spine.

Elizabeth Porter Gould's oblong anthology of Whitmanian excerpts published by McKay in 1889, Gems from Walt Whitman, is the only Whitman book that uses the poet's signature as part of the title printed on the cover (Figure 6). As Folsom points out, the color, typeface, facsimile signature, and decorative elements of Gems are all reminiscent of the cover of November Boughs-yet with one important distinction. On the cover of November Boughs Whitman's signature identifies his authorship; with Gould's volume, the autograph is also absorbed into the title of the book. Whitman's familiar signature appears, but there is no other indication of the book's creator. Of course, another "Walt Whitman" on the cover may have simply seemed redundant, but the presence of Whitman's name-though not as a separate signature claiming ownership - is an apt representation of the poet's attitude towards the collection. Whitman had maintained that "any volume of extracts must misrepresent" Leaves of Grass and that he didn't "shine in bits" ( $W W W C, 1: 282,2: 88$ ). "These gems, extracts, specimens, tid-bits, brilliants, sparkles, chippings," he tells Traubel, "oh, they 
are all wearisome: they might go with some books . . . but Leaves of Grass is different" ( $W W W C, 3: 395-396)$. As for supporting Gould's collection, Whitman was at best indifferent, claiming, "the only thing I really promised was that I would not raise a hell of an objection to it" ( $W W W C, 4: 72$ ). The cover of Gems shows Whitman's name being put to use without the poet's spirited endorsement. In its odd way-by separating the facsimile autograph from its function as a discrete attribution of authorship - Gould's book is the most explicit use of Whitman's signature as a pliable brand symbol.

Once the last edition of Leaves of Grass was published, Whitman placed several copies aside for his close friends, including Horace Traubel and Richard Maurice Bucke. The poet saw Traubel nearly each day, but he could not bring himself to sign the book that already featured his goldstamped autograph. "I have been so broke up —indeed, I am so lame-my right arm is lame, lame," Whitman confides to Traubel; "I can't write" (WWWC, 9:505). When Whitman received an order for books including his signature, he was forced to admit he was unable to offer the same "honest" marketing device he introduced in 1876. "I can't autograph," the poet tells Traubel on March 24, 1892 ( $W W W C, 9: 590$ ). Two days later, Whitman was dead.

Even as age and sickness threatened Whitman's signature, his autograph's continued presence on the cover of Leaves of Grass maintained the poet's association with the "real unaffected originality" that admirers had located in his script (Ingram 149). As Whitman's hand became less his own, the poet's autograph took on an even more vital role in identifying Leaves of Grass and its author for literary consumers.

\section{Columbia Grammar \& Preparatory School}

\section{NOTES}

1 Horace Traubel, With Walt Whitman in Camden, 9 vols. (various publishers, 19051996), 3:55. Hereafter, $W W W C$. Available on the Walt Whitman Archive (whitmanarchive.org).

2 Traubel describes a similar incident involving an autograph request from a young girl: "Some Boston girl writes me a long letter for W.'s autograph-almost pathetic in its exhortation. I gave it to W., with the return stamped envelope. He addressed it mock-seriously - 'Mr. Stamp-I am very much afraid I shall confiscate you and consign the rest of you to the fire.' I said - 'I'm afraid you will, too.' W. then-'How well-how good a hand-Miss Lady writes! It is a relief to look at the like'-and carefully put the stamp away" ( $W W W C, 6: 47-48$ ). 
3 I am indebted to David Haven Blake's book-length study of Whitman and nineteenth-century models of fame and notoriety, Walt Whitman and the Culture of American Celebrity (New Haven: Yale University Press, 2006), 3. Addressing Whitman's use of the facsimile signature, Blake argues that, much like photographs, "the facsimile autograph created the illusion of cultlike aura in an age of mechanical reproduction" (42).

4 Thornton's third chapter, "Romance and the Science of Individuality," provides a superb introduction to the multivalent functions of the signature during the nineteenth century. Though Thornton only briefly discusses autograph collecting, she does engage the emergence of handwriting analysis at length. See Tamara Plakins Thornton, Handwriting in America: A Cultural History (New Haven: Yale University Press, 1996), 73-107.

5 Jacques Derrida, "Signature Event Context," translated by Samuel Weber and Jeffrey Mehlman, Limited Inc. (Evanston, IL: Northwestern University Press, 1988), 20.

6 As Josh Lauer notes, Derrida "dismisses the notion of the signature as a unique marker of identity and intention, a proposition that he claims is undone by the fact that the actual variability of one's signature never matches the idealized, iterable version that serves as its model. Indeed, it is precisely such variation, such deviation from the model, that makes forgery possible" ("Traces of the Real: Autographomania and the Cult of the Signers in Nineteenth-Century America," Text and Performance Quarterly 27.2 [2007], 146).

7 Loren Glass, Authors Inc.: Literary Celebrity in the Modern United States, 1880-1980 (New York: New York University Press, 2004), 81.

8 Walt Whitman, The Correspondence, 7 vols., vols. 1-6, ed. Edwin Haviland Miller (New York: New York University Press, 1961-1977); vol. 7, ed. Ted Genoways (Iowa City: University of Iowa Press, 2004), 4:383. Hereafter, Corr.

9 William Powell Frith, fohn Leech, His Life and Work (London: Richard Bentley, 1891), 2:229.

10 A.M. Broadly, Chats on Autographs (London: T. Fisher Unwin, 1910), 40; hereafter, Chats.

11 “About Autographs, or Autograph Mania," Appleton's fournal of Literature, Science and Art (February 19, 1870), 213.

12 Ibid., 213.

13 William S. Walsh, Handy Book of Literary Curiosities (Philadelphia: J. B. Lippincott, 1892), 71.

14 Grant Allen, "My Lares and Penates," The American Magazine (October 1887), 721.

15 Horace Mayhew, "Autograph Hunters," George Cruikshank's Table-Book, ed. Gilbert Abbott à Beckett (London: George Bell \& Sons, 1878), 280.

16 “The Autograph-Hunter and His Prey," The Speaker (January 21, 1893), 71.

17 “The Contributors' Club,” Atlantic Monthly (April 1884), 581-582.

18 "The Autograph-Hunter and His Prey," 71.

19 "Autograph Collecting as a Business," The Literary World (June 30, 1883), 208. 
20 Ibid., 208.

21 Records of Members of the Grand Army of the Republic with a Complete Account of the Twentieth National Encampment, ed. William H. Ward (San Francisco: H.S. Crocker, 1887), 173.

22 The Charles E. Feinberg Collection of the Papers of Walt Whitman, Library of Congress, Washington, D.C. As the Walt Whitman Archive continues to transcribe, encode, and digitize Whitman's correspondence, manuscripts, and marginalia, Whitman's practice of recycling paper from autograph requests will become even more apparent to scholars. Other examples from the Feinberg Collection alone include Alice G. Brown's January 4, 1884, letter to Whitman which simply asks, "Will you kindly favor me with your autograph." On the reverse side of Brown's request, Whitman drafted notes for an article about himself entitled "Walt Whitman in Camden" (The Critic, February 28, 1885). Folger McKinsey's June 10, 1884, letter to Whitman is yet another example. After visiting Whitman's house while the poet was away, McKinsey left a book for Whitman to sign (presumably, from the context of the letter, $A s$ a Strong Bird on Pinions Free) and sent a note stating he would "treasure [the book] more closely" if Whitman signed it. On the back of McKinsey's self-described "boyish note," Whitman wrote a draft of "Of that blithe throat of thine."

23 St. Louis Globe-Democrat (November 26, 1876), 12.

24 James Huneker, Ivory Apes and Peacocks (New York: Charles Scribner's Sons, 1917), 22.

25 [Henry Cuyler Bunner] V. Hugo Dusenbury, "His Warning to AutographHunters," Puck (November 10, 1880), 156.

26 Horace Traubel describes one such incident on August 3, 1888: “Today a woman came in whose husband had been one of W.'s fellow clerks in Washington. She asked for an autograph, which W. gave her on a slip of paper. 'And a sentiment,' she added, offering to pass the slip back. W. took no notice of the slip but quietly said: 'That is all.' She withdrew" (WWWC, 2:83).

27 Broadly, Chats, 40.

28 Edward W. Bok, The Americanization of Edward Bok (New York: Charles Scribner's Sons, 1920), 43.

29 In a published family history, Foster is credited as having "a refined literary taste," producing "many beautiful poems and short stories [that] found their way from his pen into eastern newspapers and magazines." See Frederick Clifton Pierce, Foster Genealogy, Being the Record of Posterity of Reginald Foster, Vol. 2 (Chicago: W.B. Conkey, 1899), 861.

30 Edward W. Bok, "How I Made My Autograph Album," Lippincott's Monthly Magazine (May 1889), 745.

31 "The Contributor's Club," 581.

32 Clifton Johnson, "The Autograph Hunter's Treadmill," The Bookman (April 1895), 170.

33 "A Commercial View of Autographs," The Literary World (September 5, 1885), 304. 
34 Bok reprints Twain's typed response in The Americanization but does not mention the fact it was typewritten. Instead, Twain's letter is described as a "personality letter," not simply an autograph, but a letter which demonstrates the writer's character.

35 See Ed Folsom, "The Mystical Ornithologist and the Iowa Tufthunter: Two Unpublished Whitman Letters and Some Identifications," Walt Whitman Quarterly Review 1 (Summer 1983), 18-29.

36 The advertisement Rossetti mailed along with his December $16^{\text {th }}$ letter appears in The Athenaeum (December 14, 1867), 819.

37 “Walt Whitman," Chambers's Fournal of Popular Literature, Science, and Art 45 (July 4, 1868), 420-425.

38 Edgar Allan Poe, “A Chapter on Autography [Part I]," Graham's Magazine (November 1841), 224.

39 [John H. Ingram] Don Felix de Salamanca, The Philosophy of Handwriting (London: Chatto \& Windus, 1879), 3.

40 Scholarly discussion of facsimile signatures often vaguely evokes the aura's fate in the age of mechanical reproduction, but it is worth considering the specific photomechanical process used to create facsimile signatures. Line etching not only involved tracing the signature in mirror image during the preparation of the die, but the actual "writing" of the facsimile took place in relief. Cathleen A. Baker describes the process in detail in From the Hand to the Machine: Nineteenth-Century American Paper and Mediums (Ann Arbor: The Legacy Press, 2010): "This photomechanical technique, which utilized full hardening and a warm water wash, was used primarily to reproduce original line drawings. First, the printing plate-usually zinc-was coated with photosensitized gelatin. Coating was done by spinning the plate as the solution was carefully poured on in the center; this resulted in a thin, even layer with no brush or roller marks. The plate was dried and stored in the dark until ready for use. . . In the darkroom, the photographic negative was laid on the plate, wrong-reading side up, and exposed to strong light. In the clear areas of the negative, the light was absorbed by the gelatin and hardened it; the unexposed gelatin remained soft. The plate was washed in warm water to dissolve the soft gelatin, revealing bare areas of metal. The plate was then placed in an acid bath, and the bare metal was etched; these areas were non-printing. After the remaining gelatin was removed, large non-printing areas were routed out to deepen them. The finished plate was then tacked onto a wood block to make it type-high and printed on the relief press, often along with type" (194-195).

41 "Walt Whitman's Works, 1876 Edition," The New Republic (March 11, 1876), 2.

42 See Leon Jackson, The Business of Letters: Authorial Economies in Antebellum America, Stanford, CA: Stanford University Press, 2008.

43 This advertisement is reprinted in Joel Myerson, Walt Whitman: A Descriptive Bibliography (Pittsburgh: University of Pittsburgh Press, 1993), 72. The same year the Centennial edition appeared, Whitman published Memoranda During the War, which was designed and advertised as a "Remembrance Copy," a pre-planned presentation copy of Whitman's prose inscribed to (but not autographed for) the buyer or recipient.

44 Meredith L. McGill, “The Duplicity of the Pen," Language Machines: Technologies of Literary and Cultural Production, ed. Jeffrey Masten, Peter Stallybrass, and Nancy Vickers (New York: Routledge, 1997), 40. 
45 Sylvester Baxter, "Whitman's Complete Works," The Boston Herald (January 3, 1889), 4.

46 Folsom, Whitman Making Books / Books Making Whitman (Iowa City: Obermann Center for Advanced Studies, 2005), 62. Folsom's beautifully illustrated catalog and commentary gives a full and swift history of Whitman as a bookmaker.

47 John G. Cawelti, “The Writer as Celebrity: Some Aspects of American Literature as Popular Culture," Studies in American Fiction 5 (1977), 164.

48 Lauer notes how, from a modern reader's standpoint, the "fluctuating reputations" of nineteenth-century literary celebrities render some of their names "hopelessly obscure," a "testament to the selectivity of historical memory" especially apparent in periodical reprinting of autographs (144).

49 Julia Miller, Books Will Speak Plain: A Handbook for Identifying and Describing Historical Bindings (Ann Arbor, MI: The Legacy Press, 2010), 150.

50 Richard Minsky, The Art of American Book Covers, 1875-1930 (New York: George Braziller, 2010), 9.

51 Sue Allen and Charles Gullans, Decorated Cloth in America: Publisher's Bindings, 1840-1910 (UCLA Center for $17^{\text {th }}$ - and $18^{\text {th }}$-Century Studies, 1994), 14. 